JPASDEV

Journal of Public Administration

and Sociology of Development

Vol. 1, N0.1, Juli 2020

\title{
Proses Implementasi Kebijakan Pengelolaan Sampah Di Kota Putussibau
}

\author{
M. Bessiar ${ }^{1}$ \\ 1. Badan Pengelolaan Perbatasan Kabupaten Kapuas Hulu
}

Korespondesi Penulis: m.bessiar@yahoo.com

\begin{abstract}
The fundamental problem of the research is the policy implementation program of waste management in Kapuas Hulu is not as expected. Therefore, The responsibility of waste management program must be handled by all of the local government and the other stakeholders. The research aim is to describe and analyze the policy process of the implementation program. The research type is a survey research by the descriptive model. There are four Kelurahan in the research, namely Kelurahan Putussibau Kota, Kelurahan Hilir Kantor, Kelurahan Kedamin Hulu and Kedamin Hilir. The research result shows that the compliance of the implementers is in the Standard Procedure Operational. But, in the legal aspect is not optimally performed. The recommendation of this research is the local government, such as Dinas Lingkungan Hidup, Perumahan Rakyat dan Kawasan Permukiman, must be immediately issued the local regulation on waste management. Besides, the local government must plan and establish the derivative regulation of the local regulation.
\end{abstract}

Key words : The policy implementation program of waste management , Compliance, What's Happening 


\section{PENDAHULUAN}

Pertambahan jumlah penduduk yang pesat berdampak terhadap pada peningkatan jumlah sampah yang di Perumahan Rakyat dan Kawasan hasilkan. Peningkatan jumlah sampah Permukiman Kabupaten Kapuas Hulu yang tidak diikuti oleh perbaikan dan sebenarnya telah di atur melaluiPeraturan peningkatan sarana dan prasarana Daerah No. 4 Tahun 2011 tentang pengelolaan sampah mengakibatkan Retribusi Pelayanan Persampahan / permasalahan sampah menjadi komplek, Kebersihan dan Peraturan Bupati No.80 antara lain sampah tidak terangkut dan Tahun 2018 tentang Kebijakan dan terjadi pembuangan sampah sembarangan, Strategi Daerah Kabupaten Kapuas Hulu sehingga dapat menimbulkan berbagai dalam Pengelolaan Sampah Rumah dampak seperti timbulnya penyakit, kota Tangga dan Sampah Sejenis Sampah menjadi kotor, bau tidak sedap, Rumah Tangga. Namun implementasi mengurangi daya tampung sungai dan Peraturan Daerah ini belum efektif lain-lain.

Pada kota-kota besar dan sedang di Indonesia, kemampuan PEMDA dalam menangani sampah masih terbatas. Secara nasional, sampai tahun 2017, tingkat pelayanan baru mencapai $6,8 \%$ dari volume sampah yang dihasilkan. Sampah yang tidak terkelola dengan baik merupakan salah satu penyebab makin meningkatnya pencemaran air, tanah dan udara serta meningkatkan potensi banjir di perkotaan.Permasalahan persampahan perlu ditangani secara serius dengan teknis, operasional dan manajemen yang tepat dan terpadu berdasarkan kondisi dan kebijakan daerah masing-masing.

Pengelolaan sampah saat in berdasarkan UU No 18 Tahun 2008 dan memerlukan Anggaran yang sangat PP No 81 Tahun 2012 di lakukan dengan minim untuk Operasional dan dua fokus utama yakni pengurangan dan Pemeliharaan dalam pelaksanaan penanganan sampah.Pengurangan sampah pengelolaan sampah yang meliputi Gaji seperti yang di jelaskan di dalam Undang- Tenaga/petugas, Bahan Bakar Minyak, Undang maupun Peraturan Pemerintah Bengkel, TPS, TPA dan lain - lain yang telah disebutkan dilakukan mulai (Pengelolaan sampah DLHPRKP Kab. dari sumber sampah sampai pada KH, 2019). 
Data pengelolaan sampah Perumahan Rakyat dan Kawasan DLPRKP tahun 2019 sampah yang Pemukiman Kabupaten Kapuas Hulu tertangani yaitu 578 ton/tahun dan khususnya tetapi juga menjadi tanggung Produksi sampah 1.316 ton/tahun jawab semua pihak.

menunjukkan bahwa dari produksi Dalam konteks studi kebijakan, sampah dan sampah yang ditangani masih permasalahan dalam pengelolaan sampah sangat jauh dari harapan. di Kabupaten Kapuas Hulu, khususnya di

Seperti halnya Kabupaten Kapuas Kota Putussibau belum berjalan Hulu yang dihadapkan pada pembiayaan efektif.Hal ini tentu menimbulkan pengelolaan sampah. Kebutuhan anggaran pertanyaan padapelaksanaan kebijakan tersebut di biayai sendiri dari pendapatan yang dilakukan dalam pengelolaan yang diperoleh dari pengelolaan sampah sampah tersebut. Sejalan dengan itu, tersebut berupa retribusi, sementara penulis menetapkan ruang lingkup usaha- usaha lain untuk peningkatan penelitian sebagai berikut :"mengapa pendapatan belum dilaksanakan dengan belum optimalnyaimplementasi kebijakan baik. Sektor pengelolaan persampahan pengelolaan sampah di Kota sumber dana pendapatan sebagaitolok Putussibau”.

ukur pengelolaan yang self-finance (mampu dibiayai sendiri) adalah penerimaan retribusi .

Adapun beberapa permasalahan dalam implementasi kebijakan pengelolaan sampah di Kota Putussibau adalah sebagai berikut:

1. Belum patuhnya implementor kebijakan pengelolaan sampah di Kota Putussibau

2. Masih banyak terjadinya pelanggaran kebijakan dalam pelaksanaan pengelolaan sampah

Masalah yang menjadi dasar dilakukan penelitian ini adalah bahwa prosesimplementasi kebijakan pengelolaan persampahan di Kota Putussibau yang masih sangat rendah. Untuk itu upaya implementasi kebijakan pengelolaan sampah perlu dilakukan agar pengelolaan sampah tidak hanya menjadi Tanggung Jawab Pemerintah daerah umumnya dan Dinas Lingkungan Hidup,

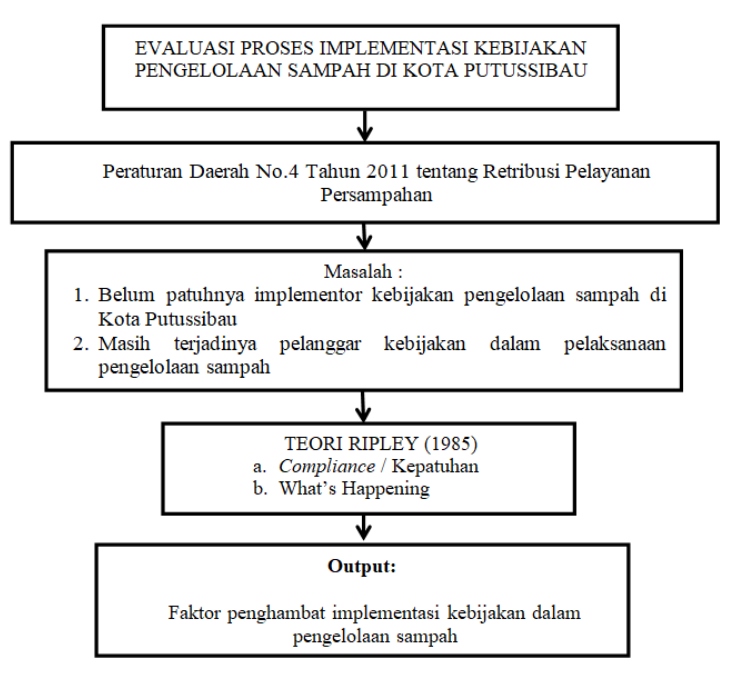

Gambar 1.1 Alur Pemikiran

\section{METODE PENELITIAN}

Jenis penelitian yang digunakan dalam penelitian ini adalah penelitian kualitatif. Menurut Sugiyono (2009:9) metode penelitian kualitatif adalah metode penelitian yang berlandaskan pada 
filsafat postpositivisme, digunakan untuk dengan keadaan yang sebenarnya yang meneliti pada kondisi objek yang alamiah terjadi di lapangan.

(sebagai lawannya adalah eksperimen)

Analisis data pada penelitian dimana peneliti adalah sebagai instrumen kualitatif meliputi tahap-tahap sebagai kunci,teknik pengumpulan data dilakukan berikut (Milles and Huberman, 1992): secara triangulasi (gabungan), analisis 1. Reduksi Data data bersifat induktif/kualiatif, dan hasil 2. Penyajian Data penelitian lebih menekankan makna 3. Penarikan Kesimpulan daripada generalisasi.

Triangulasi metode dilakukan

Penelitian ini dilaksanakan dengan cara membandingkan informasi diKotaPutussibau yang meliputi4 (empat) atau data dengan cara yang berbeda. kelurahan meliputi Kelurahan Putussibau Dalam penelitian kualitatif peneliti Kota, Kelurahan Hilir Kantor, Kelurahan menggunakan metode wawancara, Kedamin Hulu dan Kedamin Hilir. obervasi, dan survei. Untuk memperoleh

Subjek penelitian adalah tempat kebenaran informasi yang handal dan dimana data untuk variabel penelitian gambaran yang utuh mengenai informasi diperoleh (Arikunto,2010) Subyek dalam tertentu,peneliti bisa menggunakan penelitian ini adalah Kasi Pengelolaan metode wawancara dan obervasi atau Sampah dan Limbah B3 DLHPRKP, pengamatan untuk mengecek patugas angkut, pekerja lapagan/petugas kebenarannya. Selain itu, peneliti juga kebersihan dan masyarakat.Penentuan bisa menggunakan informan yang berbeda subyek penelitian tersebut menggunakan untuk mengecek kebenaran informasi teknik purposive. tersebut. Triangulasi tahap ini dilakukan

Dalam melakukan penelitian ini jika data atau informasi yang diperoleh penulis melakukan tehnik pengumpulan dari subjek atau informan penelitian data sebagai berikut : diragukan kebenarannya.

1. Wawancara.

2. Dokumentasi

3. Observasi

Implementasi merupakan proses

Berdasarkan pada jenis penelitian yang digunakan adalah penelitian deskriptif, maka dari data yang tekumpul, akan dianalisa dengan menggunakan analisa kualitatif yaitu dengan cara melukiskan hasil penelitian hasil penelitian dalam bentuk kata-kata atau kalimat-kalimat sehingga dengan demikian penulis menguraikan secara mendalam hasil penelitian tersebut sesuai penting dalam suatu kebijakan. Dengan implementasi terhadap kebijakan yang dibuat oleh pemerintah, maka dapat dilihat dampak dari kebijakan tersebut terhadap target sasaran dari kebijakan yang telah dibuat. Banyak kebijakan yang tidak jelas dampak dan manfaatnya terhadap target sasaran, dikarenakan proses implementasi yang tidak sesuai dengan apa yang ditulis dalam kebijakan tersebut, bahkan kebijakan tersebut tidak diimplementasikan atau tidak 
dilaksanakan. Efektifnya suatu implementasi kebijakan dipengaruh oleh variabel-variabel serta indikator penentu kebijakan.variabel-variabel tersebut saling mempengaruhi satu sama lainnya, sehingga mampu menciptakan implementasi yang efisien. Dalam penelitian Implementasi Kebijakan pengelolaan Sampah di Kota Putussibau, peneliti menggunakan model implementasi kebijakan Randall B. Ripley dan Grace A. Franklin yang menggunakan dua variabel utama yaiut kepatuhan(compliance) dan what's happening and why? (apa yang terjadi dan kenapa.

\section{HASIL DAN PEMBAHASAN}

Implementasi merupakan proses penting dalam suatu kebijakan. Dengan implementasi terhadap kebijakan yang dibuat oleh pemerintah, maka dapat dilihat dampak dari kebijakan tersebut terhadap target sasaran dari kebijakan yang telah dibuat. Banyak kebijakan yang tidak jelas dampak dan manfaatnya terhadap target sasaran, dikarenakan proses implementasi yang tidak sesuai dengan apa yang ditulis dalam kebijakan tersebut, bahkan kebijakan tersebut tidak diimplementasikan atau tidak dilaksanakan. Efektifnya suatu implementasi kebijakan dipengaruh oleh variabel-variabel serta indikator penentu kebijakan.variabel-variabel tersebut saling mempengaruhi satu sama lainnya, sehingga mampu menciptakan implementasi yang efisien. Dalam penelitian Implementasi Kebijakan pengelolaan Sampah di Kota Putussibau, peneliti menggunakan model implementasi kebijakan Randall B. Ripley dan Grace A. Franklin yang menggunakan dua variabel utama yaiut kepatuhan(compliance) dan what's happening and why? (apa yang terjadi dan kenapa?) yang akan dijelaskan dalam sub bab berikut ini :

\section{Kepatuhan (Compliance)}

Ripley dan Franklin menjelaskan variabel compliance sebagai tingkat kepatuhan implementor dalam bertindak, apakah sesuai dengan ketentuan dan mematuhi peraturan yang ditetapkan dalam kebijakan. Tingkat kepatuhan implementor terhadap kebijakan merupakan salah satu tolak ukur keberhasilan dari implementasi kebijakan tersebut. Pendekatan kepatuhan mengacu pada perilaku implementor itu sendiri, apakah sesuai dengan standar dan prosedur serta aturan yang telah ditetapkan oleh kebijakan. Serta melihat sejauh mana pemahaman implementor dalam melaksanakan tugas yang telah diberikan dan sesuai dengan apayang ada dalamkebijakan.

Kebijakan yang mengatur bagaimana pelaksanaan Pengelolaan sampah yang diatur dalam Peraturan Daerah No. 4 Tahun 2011 tentang Retribusi, Pelayanan Persampahan/Kebersihan. Peraturan ini menjadi pedoman bagaimana implementor bertindak dalam melaksanakan program. Untuk melihat bagaimana tingkat kepatuhan implementor dilapangan maka dapat dilihat dari dua sisi, yaitu pertama adalah 
bagaimana implementor memahami Dimana, setiap implementor memiliki petunjuk teknis program sehingga mampu tugas dan tanggung jawab masingmenterjemahkan kebijakan dalam bentuk masing yang sesuai dengan tupoksi dari tindakan yang nyata, hal ini berkaitan OPD.Agar para implementor dapat dengan bagaimana proses transfer mengetahui, mengerti dan memahami isi informasi terjalin antara para implementor dari sebuah kebijakan, diperlukannya sehingga semua informasi tersampaikan sosialisasi kebijakan tersebut.Hasil dari dengan baik dan dapat dipahami dengan penelitian ini, hampir semua baik. Serta yang kedua adalah bagaimana implementor tidak mengetahui, mengerti implementor berperilaku dilapangan dan memahami isi dari kebijakan tentang sesuai dengan standar peraturan yang pelaksaaan pelayanan persampahan dan telah ada, dan melihat apakah perilaku kebersihan yang dilaksanakan.Secara implementor tersebut merupakan bentuk keseluruhan, implementor mengetahui dukungan terhadap pelaksanaan program tentang kebijakan pelaksaaan pelayanan atau tidak. persampahan dan kebersihan yang dilaksanakan di Putussibau.Namun, Pemahaman implementor terhadap mengenai tupoksi-nya, implementor kebijakan belum melaksanakan secara Dalam pelaksanaan sebuah maksimal.Seperti hal-nya ketika peneliti kebijakan/program, implementor harus bertanya mengenai pelaksanaan tupoksi memahami isi kebijakan dan petunjuk kepada implementor, dengan menjawab, teknis yang berkaitan dengan setiap pelaksanaan pengelolaan sampah lebih di langkah dan proses implementasi suatu tekankan lagi pelaksanaannya di petugas kebijakan, sehingga dalam pelaksanaan persampahan.

kebijakan tersebut tidak terjadi kesalahan

Ketidaktahuan dari implementor dan kekeliruan yang berkaitan dengan terhadap Juklak pengelolaan sampah tugas dan fungsi implementor dilapangan yang dikeluarkan oleh kepala daerah, nantinya. Pemahaman implementor dapat menyebabkan kekeliruan terhadap terhadap isi kebijakan akanberimplikasi pelaksanaan tugas oleh implementor pada sikap implementor, yang akan tersebut.Hal ini dapat disebabkan oleh menunjukan sikap mendukung atau tidak kurangnya sosialisasi dari pemegang dalam sebuah pelaksanaan program.

Kebijakan pengelolaan sampahdi Putussibau dilaksanakan oleh Dinas Lingkungan Hidup, Perumahan Rakyat dan Kawasan Pemukiman Kabupaten Kapuas Hulu khususnya pada seksi pengelolaan sampah dan limbah B3 sebagai leading sector, pengawas dan petugas sampah sebagai implementor. kebijakan.Sehingga Implementor harus mencari tahu sendiri. Namun implementor beralih bahwa PERDA tersebut hanya merupakan perpanjangan dari Peraturan Menteri, jadi secara keseluruhan itu sama saja. Jadi mereka merasa tidak peru tahu tentang adanya perda tersebut. Hal ini lah yang dapat mengakibatkan tidak selarasnya antara 
tugas yang ada didalam perwako dengan yang dilaksanakan oleh implementor.

Selain dari data wawancara, pahamnya implementor terhadap kebijakan dapat dilihat dari bagaimana kemampuan implementor menerjemahkan kebijakan dalabentuk memasukkan program dan kegiatan dalam bentuk tindakan nyata yang berhubungan untuk mendukung jalannya kebijakan pengelolaan sampah in dapat dilihat pada tabel berikut ini:

\section{Perilaku Implementor}

Perilaku implementor dapat dilihat dari bagaimana sikap implementor dalam mengimplementasikan kebijakan pengelolaan sampah. Kesesuaian sikap implementor yang terlibat dengan kebijakan yang mengatur pelaksanaan kebijakan pengelolaan sampah. Dimana seluruh implementor mempunyai tugas pokok masing-masing yang sudah diatur dalam perda.

Berdasarkan Peraturan Daerah Nomor 4 tahun 2011 tentang Retribusi Pelayanan Persampahan/kebersihan, terdapat tugas masing-masing implementor dan belum mengatur fungsi dari pada implementor. Peraturan ini menjadi pedoman bagi implementor dalam bertindak dalam melaksanakan kebijakan pengelolaan sampah untuk mencapai tujuan yang telah ditentukan. Berikut akan peneliti jelaskansatupersatuperilakuyangditunjukanolehimple mentor dalam melaksanakan program berdasarkan tugas dan fungsinya masing- masing, seperti dibawah ini:

Dinas Lingkungan Hidup, Perumahan

\section{Rakyat dan Kawasan Permukiman} Kabupaten Kapuas Hulu.

Dalam Dinas Lingkungan Hidup Perumahan Rakyat dan Kawasan Permukiman Kabupaten Kapuas Hulu merupakan dinas baru terbentuk dan dalam pelaksanaannya mengikuti nomenkulatur provinsi yaitu pengabungan dua lembaga/kementrian.

\section{What's Happening and Why (Apa YangTerjadi dan mengapa)}

Pendekatan ini menanyakan bagaimana implementasi berjalan, tujuan yang sedang dicapai, bagaimana keberhasilan implementasi dilandasi dengan lancarnya rutinitas fungsi dan tidak adanya masalah-masalah yang dihadapi. Terkait dengan variabel ini, penelitian Implementasi Kebijakan pengelolaan Sampah di Kota Putussibauyang peneliti lakukan ingin melihat bagaimana implementasi berjalan, siapakah implementornya, bagaimana sejumlah sumber digunakan selama implementasi berlangsung, dan hambatan-hambatan apa yang timbul saat implementasi Kebijakan pengelolaan Sampah.

Variabel What's Happening terbagi atas lima indikator, agar dapat mengukur pelaksanaan suatu program. Yang akan peneliti jelaskan pada bagian dibawah ini, yaitu:

\section{Banyaknya Aktor yang Terlibat (The Profusion ofActors)}

Indikator ini menjelaskan bahwa proses implementasi tidak hanya melibatkan satu aktor saja, melainkan banyak aktor. Implementor yang terlibat dalam 
implementasi suatu program tidak hanya yang ada pada ruang lingkup pemerintahan dan birokrat, namun juga melibatkan aktor diluar pemerintahan seperti organisasi non pemerintah yang disebutkan sebagai pihak yang berkepentingan.

\section{Jumlah dan Identitas (Number and Identity)}

Dalam indikator ini, number dijelaskan sebagai siapa saja aktor-aktor yang terlibat dalam proses implementasi atau berapa banyak aktor yang terlibat. Dalam penelitian yang peneliti lakukan, implementor yang terlibat yaitu lebih kurang sebanyak 3elemen, yaituSeksi Pengelolaan Sampah dan Limbah B3, Petugas Pengawas, dan Petugas Sampah. Untuk tabel aktor yang terlibat dapat dilihat pada tabel berikut ini:

Tabel 1.

Implementor Yang terlibat dalam

Pelaksanaan Kebijakan Pengelolaan Sampah di Kota Putussibau

\begin{tabular}{|r|l|c|}
\hline No. & \multicolumn{1}{|c|}{ Aktor } & $\begin{array}{c}\text { Instansi } \text { I } \\
\text { organisasi }\end{array}$ \\
\hline 1. & $\begin{array}{l}\text { Seksi Pengelolaan } \\
\text { Sampah dan } \\
\text { Limbah B3 }\end{array}$ & $\begin{array}{c}\text { Dinas } \\
\text { Lingkungan } \\
\text { Hidup,PRKP }\end{array}$ \\
\hline 2. & Petugas Pengawas & $\begin{array}{c}\text { Lingkungan } \\
\text { Hidup,PRKP }\end{array}$ \\
\hline 3. & Petugas Sampah & $\begin{array}{c}\text { Dinas Lingkungan } \\
\text { Hidup,PRKP }\end{array}$ \\
\hline
\end{tabular}

Sumber : Hasil Olahan Peneliti, 2020

Dari Tabel 1 diatas dapat dilihat banyaknya aktor yang terlibat dalam pelaksanaan Kebijakan Pengelolaan
Sampah di Kota Putussibau.

Sedangkan Identity mengacu pada kedudukan (Tupoksi) implementor dalam suatu kebijakan. Dimana peran Instansi/orgsanisai/ lembaga/ kelompok ini sangat berperan dengan mendukung pelaksanaan yang dilakukan Dinas Lingkungan hidup, Perumahan Rakyat dan Kawasan Permukiman Kabupaten Kapuas Hulu dalam pengelolaan sampah.Instansi/orgsanisai/lembaga/kelo mpok memiliki peran masing-masing dalam perbantuan dinas DLHPRKP Kabupaten Kapuas Hulu. Yang akan dilihat pada penelitian ini adalah bagaimana implementor yang terlibat dalam peran DLHKPR Kabuapten Kapuas Hulu untuk pelaksanaan pengelolaan sampah yang diatur dalam Peraturan DaerahNo 4 Tahun 2011 tentang Retribusi, Pelayanan/Kebersihan Sampah.

Dari pemaparan diatas, dilihat dari model implementasi Ripley dan Franklin dapat diketahui bahwa dari segi jabatan maka dapat dikatakan bahwa implementor telah sesuai dengan implementasi.Begitu juga dengan aktor seperti Organisasi Pramuka, Radio Sika, dan Duta Lingkungan sudah sangat mencukupi jumlahya untuk melaksanakan implementasi kebijakan. Sedangkan dari segi identity petunjuk implementasi belum mengatur sedemikian rupa mengenai petunjuk pelaksana ,petunjuk teknis, tugas pokok dan fungsi dari implementor yang satu dan yang lainnya, sehingga implementor tidak dapat bekerja sesuai dengan peran masing-masing sehingga terjadi tumpang 
tindih pekerjaan. Dan, dalam pelaksanaan tupoksi implementor masih belum maksimal, karena sebagianbesar dari implementor tidak mengetahui apa tupoksi nya, dengan alasan mereka tidak pernah mendapatkan sosialisasi tentang Peraturan Daerah No. 4 Tahun 2011 tentang Retribusi Pelayanan Persampahan/kebersihan.

Peran dari Pihak yang berkepentingan (The Role of Interest Group)

Peran dari kelompok kepentingan yang dimaksud dalam indikator ini adalah sejauh mana kelompok kepentingan mendukung atau tidak kebijakan. Sebuah program tidak hanya ditentukan oleh kebijakan saja, namun secara langsung maupun tidak langsung juga dipengaruhi oleh kelompok kepentingan yang berada di dalam dan luar lingkup kebijakan. Dalam penelitian yang telah peneliti lakukan ini, peneliti melihat apakah ada kelompok kepentingan seperti Organisasi Pramuka (Saka Kalpataru, Kwarcam Kapuas Hulu) yang bergerak dalam bidang lingkungan, Radio Sika sebagai Media Massa, Duta Lingkungan Hidup dalam menyampaikan secara langsung kepada masyarakat dan Kelompok TPS 3R dalam pengurangan, pemilahan dari sumbernya dan pendaur ulang sampah, yang ikut berpartisipasi dalam melaksanakan kebijakan pengelolaan sampah di Kota Putussibau.

\section{Organisasi Pramuka}

Organisasi Pramuka merupakan salah satu organisasi kepanduan yang didalam kepanduan ini dibagi bagi beberapa Saka. Saka yang aktif bergerak dalam menjaga lingkungan yaitu SAKA KALPATARU. Dalam implementasi kebijakan pengelolaan sampah, Pramuka bereperan sebagai pendukung implementasi pengelolaan sampah di Putussibau.

\section{Radio Sika (RASIKA)}

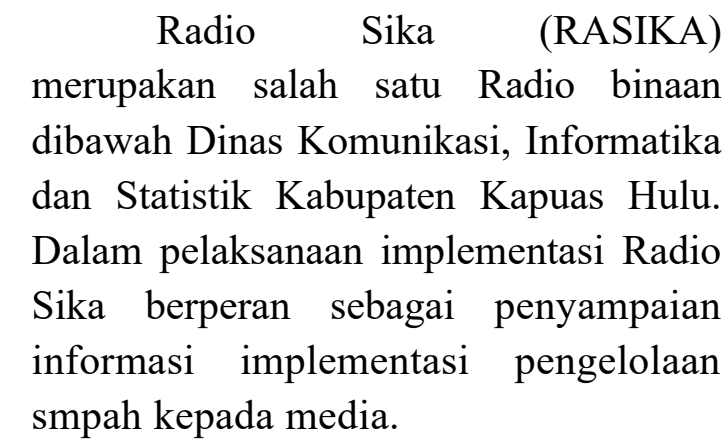

\section{Duta Lingkungan}

Duta Lingkungan hadir dalam perannya sebagai garis depan yang secara garis besar bertugas untuk menyuarakan gagasan tentang lingkungan pada masyarakat luas.

\section{Kelompok Swadaya Masyarakat (KSM) TPS 3R (Reduse, Recycle and} Recycle)

Kelompok Swadaya Masyarakat (KSM) TPS 3R ini mempunyai peran mengurangi kuantitas dan/atau memperbaiki karakteristik sampah, yang akan diolah secara lebih lanjut di Tempat Pemrosesan Akhir (TPA) sampah dan berperan dalam menjamin semakin sedikitnya kebutuhan lahan untuk penyediaan TPA sampah di perkotaan.

\section{Ketiadaaan Hirarki (Lock of Hierarchy)}

Sangat penting untuk melihat bagaimana hubungan atau ada tidaknya 
garis koordinasi antara implementor.Hubungan rantai koordinasi bahkan lebih menyebabkan kompleksitas pelaksanaan implementasi dibandingkan banyaknya yang terlibat. Adanya garis koordinasi dapat memaksimalkan proses implementasiHubungan atau garis koordinasiyang terbentuk dalam proses implementasi berupa bagaimana formal melaksanakan ataumelakukankoordinasi kepada instansi/ lembaga/organisasi/kelompokdalam pelaksanaan implementsi kebijakan pengelolaan sampah secara baik.

Dalam penelitian Evaluasi Implementasi Kebijakan Pengelolaan sampah ini, peneliti ingin melihat bagaimana garis koordinasi yang terjadi pada:

a) Hubungan antar Staf yangterlibat

b) Hubungan Organisasi/KSM dengan OPD yangterlibat.

Hubungan atau garis koordinasi yang terbentuk dari pelaksanaan implentasi kebijakan pengelolaan sampah adalah tidak adanya keharusan untuk setiap OPD yang terlibat memberikan laporan dan sanksi kepada OPD lainnya jika tidak melaksanakan koordinasi balik.Hubungan yang terjalin hanya sebatas saling mendukung dalam implementasi kebijakan pengelolaan Sampah, tidak ada kewenangan dari OPD lainnya untuk memaksa dan memeriksa pelaksanaan tugas dari OPD lainnya.

\section{a. Hubungan \\ Antar yangterlibat}

Dalam implementasi kebijakan pengelolaan sampah, seluruh dinas yang terlibat pelaksanaan menjalin hubungan dalam bentuk komunikasi dan koordinasi, dan saling membantu satu sama lainnya jika dibutuhkan.

\section{b. Hubungan Organisasi/KSM dengan OPD yangterlibat}

Kebijakan Pengelolaan sampah merupakan muara dari kegiatan kebijakan pengelolaan sampah. Pada lingkungan masyarakatkebijakan pengelolaan sampah diterapkan.Semua kegiatan masyarakat harus mencerminkan kebersihan lingkungan yang bersih dan sehat, seperti visi dan misi yang harus mencakup mewujudkan perlindungan dan pengelolaan lingkungan hidup yang berkelanjutan serta terciptanya hunian yang sehat dan produktif.Dengan visi dan misi tersebut masyarakat dapat menjalankan kebiasaan pada kehidupan sehari-hari, agar menjaga dan melestarikan lingkungan masyarakat.Dalam pelaksanaan kebijakan pengelolaan sampah, masyarakat harus berkoordinasi dengan Dinas Lingkungan Hidup, PRKP Kabupaten Kapuas Hulu. Selain itu masyarakat bekerja sama dengan OPD yang ada di Kota Putussibau, seperti dengan Pramuka, KSM Pengelola Sampah, danlain-lain.

\section{Perkembangan dan Kerumitan Program ( The Proliferation and Complexity of Goverment Programs)}

Dalam variabel ini peneliti ingin melihat sejauh mana pemerintah mempersiapkan kebijakan pengelolaan sampah, menyangkut kelengkapankelengkapan program, seperti adanya SOP (standar operasional prosedur), petunjuk pelaksanaan, dan petunjuk 
teknis yang terkait dengan pelaksanaan kebijakan pengelolaan sampah.

Kebijakan pengelolaan sampah bertujuan untuk menjaga kelestarian fungsi lingkungan hidup dan kesehatan masyarakat; serta menjadikan sampah sebagai sumber daya.

Tujuan dari kebijakan pengelolaan sampah sejalan dengan program-program pemerintah lainnya untuk menciptakan Kotabersih dan sehat. Beberapa contoh program lainnya yang memiliki tujuan yang sama dengan kebijakan pengelolaan sampah yaitu Program Adiwiyata yang pelaksanaannya diatur dalam Peraturan menteri Lingkungan Hidup No. 05 Tahun 2013 tentang Pedoman Pelaksanaan Program Adiwiyata. Berlandaskan pada Undang Undang Nomor 18 Tahun 2008 tersebut, maka Pemerintah Kabupaten Kapuas Hulu menetapkan Peraturan Daerah Nomor 4 Tahun 2011 tentang Retribusi Pelayanan

Persampahan/kebersihan.

Partisipasi semua pada unit kegiatan-kegiatan pelestarian lingkungan Pemerintah (The Participation of disekolah nya.

Governmental Unit at All Territorial Dukungan yang diberikan Levels.

Besarnya dukungan publik berupa sarana dan prasarana seperti terhadap penerimaan suatu program tempat sampah tiga warna, serta memberikan besarnya dampak positif bagi membuat pedoman pelaksanaan program proses implementasi program pemerintah. Adiwiyata. Dalam pelaksanaan Dukungan publik yang mengikuti siklus program, pemerintah mengeluarkan tertentu menimbulkan kesukaran- pedoman pelaksanaan

kesukaran tertentu, pada hakikatnya Berdasarkan temuan peneliti dukungan publik dalam menciptakan dilapangan, dan didukung dengan data keberhasilan implementasi suatu program pelengkap dan kutipan wawancara, di mensyaratkan adanya dukungan dari analisis menggunakan teori Ripley dan pemerintah.
Franklin, maka dapat peneliti simpulkan 
bahwa untuk variabel partisipasi pada semua unit pemerintah pada pelaksanaan kebijakan pengelolaan sampah sudah baik, dengan adanya kesadaran sekolah sekolah dalam pengadaan wadah sampah untuk kebersihan sekolahnya.

Faktor-faktor Yang Tidak Terkendali yang mempengaruhi Implementasi (The Uncontrollable Factors That All Affect Implementation)

$$
\text { Dalam pelaksanaan }
$$

implementasi sebuah program atau kebijakan, tidak pernah terlepas dari berbagai foktor-faktor yang dapat menghambat atau bahkan menggagalkan proses implementasi tersebut. Faktorfaktor tersebut muncul diluar kendali implementor, sehingga dapat mengganggu jalannya implementasi program yang sedang berlangsung.Untuk mengatasi berbagai faktor atau gangguan teknis yang muncul, maka diperlukan perilaku dan reaksi dari implementor untuk mengatasi faktor-faktor tersebut.

Pada pelaksanaan kebijakan pengelolaan sampah, faktor yang tidak terkendali yaitu perilaku menjaga kebersihan dari warga masyarakat atau kesadaran masyarakat akan kebersihan lingkungan, dan faktor geografis dari lingkungan masyarakat tersebut. Perilaku bersih tertanam pada pribadi manusia itu sendiri, akan sulit diarahkan jika dalam diri manusia tidak tertanam perilaku cinta lingkungan, sehingga masih kurangnya kesadaran untuk menjaga kebersihan dan merawat lingkungan. Kesulitan dalam mengarahkan warga masyarakat untuk membuang sampah pada tempat yang telah disediakan

Selain dari permasalahan diatas, terdapat faktor lain yang dapat menghambat pelaksanaan kebijakan pengelolaan sampah, diantaranya keterbatasan lahan atau letak bangunan TPS yang untuk wilayah yang belum terjangkau pelayanan sampah. Hal tersebut menjadi faktor yang tidak bisa dikendalikan, karena keterbatasan lahan dan keterbatasan dana, sehingga masih ada masyarakat yang tidak bisa terlayani. Karena dalam pengelolaan sampah diharuskan adanya beberapa komponen yang mengharuskan DLHPRKP dapat melayani, yaitu memiliki sarana dan prasarana pendukung, seperti akses menuju tempat pengumpulan sampah dapat dilalui kendaraan pengangkut sampah atau gerobak. Salah satu alternatif yaitu masyarakat menyiapkan lahan/tempat untuk TPS yang disepakati warga masyarakat dan DLHPRKP yang bisa dilewati oleh kendaraan pengakut sampah baik itu roda empat atau roda tiga. Kemudian masyarakat yang berada didalam gang membuang sampah ketenmpat TPS tersebut.

Dari hasil tersebut diatas dapat dilihat bahwa faktor yang tidak terkendali dalam pelaksanaan kebijakan pengelolaan ada beberapa faktor yang mempengaruhi yaitu, faktor manusia, dana dan faktor geografis. Faktor manusia yaitu masih kurangnya kesadaran dari warga masyarakat untuk menjaga dan merawat lingkungan.Masih banyak nya ditemukan masyarakat yang membuang sampah pada sembarang 
tempat, serta masih adanya sampah yang ditemukan berserakan. Selain itu, faktor finansial atau anggaran yang masih minim dialokasikan untuk terlaksananya kebijakan pengelolaan sampah.

\section{Simpulan dan Rekomendasi}

\subsection{Simpulan}

Kepatuhan para implementor yang terlibat dalam pengelolaan sampah (pengawas dan petugas sampah) sudah mengikuti arahan atasan dalam pelaksanaannya, namun kepatuhan dalam pelaksanaan kebijakan atau yudisial secara hukum belum optimal atau tepat sasaran. Kemudian kepatuhan masyarakat untuk membuang sampah masih disembarang tempat dan masih minimnya kesadaran untuk membuang sampah kepada tempatnya.

Implementasi

didalam

pelaksanaan kebijakan pengelolaan sampah ini Dinas Lingkungan Hidup, Perumahan Rakyat dan Kawasan Permukiman Kabupaten Kapuas Hulu telah melakukan apa yang menjadi tolak ukur, namun karena keterbatasan kapasitas armada, tempat penampungan sampah (TPS) yang dimiliki dan belum adanya pengelolaan secara sistematis mengakibatkan sampah belum sepenuhnya teratasai dengan baik.

\subsection{Rekomendasi}

Dari kesimpulan diatas dapat di ambil benang merah sebagai saran yaitu Dinas Lingkungan Hidup, Perumahan Rakyat dan Kawasan Permukiman Kabupaten Kapuas Hulu khususnya pada seksi Pengelolaan sampah dan Limbah B3 harus sesegera mungkin menetapkan
Peraturan Daerah tentang Pengelolaan sampah di Kabupaten Kapuas Hulu Segera merancang dan menetapkan turunan Peraturan Daerah menjadi Peraturan Bupati,

\section{Referensi}

Anderson. E. J.,(1997)., Public Policy Making. New York: HRW.

Bintoro., T. (1994)., Perencanaan Pembangunan. Jakarta: Haji Masagung, Jakarta. 1993.Kebijaksanaan dan Administrasi Pembangunan, Perkembangan Teori dan Praktek. Jakarrta: LP3ES.

Dye, T.R. ( 1992) . Understanding Public Policy. New Jersey: Englewood Cliffs

Dunn, W. (1999) . Manajemen Analisis Kebijakan Publik, (edisi ke dua), Yogyakarta: Gajah Mada University Press.

Edward III, G. C. (1980). Implementing Public Policy. New Jersey: Englewood Cliffs.

Gaffar, A.. (1998). Publik Policy: State Of The Disipline, Models and Proces. Yogyakarta: Pasca Sarjana Universitas Gajah Mada.

Islamy, M. I. (1997). Prinsip-prinsip Perumusan Kebijakan Negara. Jakarta: Buni Aksara.

Miles, M. B dan Huberman A, M. (1992). Analisis Data Kualitatif, Jakarta: Universitas Indonesia.

Mazmanian, D. H. And Paul A. S. (1998). Implementation and Public Policy. New York: Harper Collins.

Moleong, L. J. (2012). Metodologi Penelitian Kualitatif. Bandung: Remaja Rosdakarya.

Mustopadidjaya, A.R., (2005). 
Perkembangan Penerapan Studi Peraturan Bupati Kapuas Hulu Nomor 63 Kebijakan. Jakarta: Lembaga Tahun 2018 tentang Kebijkan dan Administrasi Negara Republik Strategi Kabupaten Kapuas Hulu Indonesia.

Nugroho, D R. (2004). Kebijakan Publik, Formulasi, Implementasi dan dalam Pengelolaan Sampah Rumah Tangga dan Sampah Sejenis Evaluasi. Jakarta: Gramedia.

Putra, F. (2001). Pradingma Kritis Dalam Studi Kebijakan Publik. Yogyakarta: Pustaka Pelajar Offet.

Randall B. .y dan Grace, A. F.(1985). Policy Implementation and Bureaucracy, Publishier Dorsey Press.

Sugiyono, (2011). Metode Penelitian Administrasi, Bandung: Alfabeta

Subarsono, AG. (2000). Analisis Kebijakan Publik: Konsep, Teori dan Aplikasi, Yogyakarta: Pustaka Pelajar.

Tangkilisan, H. N. (2003). Evaluasi Kabijakan Publik, Penjelasan, Analisis, dan Trasformasi Pemikiran Nagel. Yogyakarta: Balairung

Wahab, A.S. (2008). Analisa Kebijaksanaan. Jakarta: Buni Aksara.

Wibawa, S. (1994). Kebijaksanaan Publik Proses dan Analisis. Jakarta: Intermedia

Winarno, B..( 2008). Teori dan Proses Kebijakan Publik. Yogyakarta: Media Pressindo.

\section{Dokumen Perundang Undangan :}

Undang-Undang Nomor 25 Tahun 2009 Tentang Pelayanan Publik;

Undang-Undang Nomor 18 Tahun 2008 Tentang Pengelolaan sampah;

Peraturan Daerah Kapuas Hulu No. 4 Tahun 2011 tentang Retribusi Pelayanan Persampahan / Kebersihan 